\title{
Replik til Søren Schou
}

Søren Schou vil gerne være med til at revidere det syn på tiden før 68 som vi anlagde i tiden efter. Men han synes tydeligvis at jeg går for vidt og er blevet helt revisionistisk. Jeg er meget konciliant og for arbødig overfor Sørensen. Min lasning er beriget laesning og ikke symptomallasning, som det sig hør og bør. Beriget læsning, det lyder farligt, lidt $\mathrm{i}$ retning af beriget uran, i hvert fald kan den kun bekræfte den læsning af historierne man har i forvejen.

Men er det nu også rigtigt? Den læsning der ligger til grund for Schous kritik af En fremtidshistorie er ikke min. Jeg mener slet ikke man kan angribe historien (herunder: gå til den) på det niveau som Schou gør. Skræmmebilledet $\mathrm{i}$ historien af et totalt styret og forudkalkuleret samfundsliv kan godt virke plausibelt i Schous øjne, men kun under forudsætnig af at det drejer sig om en fremskrivning af 'autortitære korporativisme-tendenser.' Det er der bare ikke tale om hos Sørensen og derfor er der tale om 'dårlig Adorno', d.v.s. om en pessimisme uden ende. Adorno vidste i det mindste at det forvaltede samfund måtte vær isprængt noget uberegneligt for at kunne overleve. Hm. Hvad er det, der sætter Sørensens historie igang, om ikke netop det Schou efterlyser? Hvad står en figur som Filip Rose for, om ikke netop for det uberegnelige, præsidenten $\mathrm{i}$ fremtidssamfundet ikke kan få bugt med? Historien handler ikke om korporativismetendenser, det er rigtigt, men dog i høj grad om falske allicancer med det der skulle gøres op med. Filip Rose kan ikke gøre op med det autoritære samfund fordi han inderst inde hænger sammen med det, er autoritær $i$ sin befrielseskamp. Forst idet han bliver i stand til at negere samfundet bestemt, og det vil sige, da han kan gå imod det uden at være totalitær (altså også gå lidt ind for det), får han myndighed til at overvinde de falske autoriteter. Historien er kompleks, siger Schou, men vil alligevel reducere den til en historie om ødipus-myten og må så bebrejde den at de upersonlige beherskelsesforhold er svøbt i så stærkt personaliserede relationer. Bortset fra at selv det upersonlige jo dog må komme et - personligt - sted fra i sidste instans, så aktualiserer historien godt nok mange andre forhold af mytisk og historisk art end forholdet til far og mor. Det er en hel verdenshistorie i miniformat, der ikke bare fremskriver hvad der er sket, men som vil ændre den. Den er derfor heller ikke præget af 
eskatologiske forestillinger, i betydningen forestillinger om verdens undergang, men nærmest af forestillinger om det modsatte. Det forvaltede samfund betegner ikke nødvendigvis verdens undergang og opgøret med det heller ikke.

Et opgør med vores forhold til det der gik forud for 68 må baseres pă en anden forståelse af fortiden og ikke bare på en beriget, der blot bekræfter den gamle. Det drejer sig ikke uden videre om at få mere forståelse for fortiden, men at spørge om der var noget vi ikke rigtig forstod dengang. Vi er enige om at afvise en pragmatisk holdning også til litteraturen (á la Lenins til Tolstoj). Men jeg synes at Schou i for høj grad nøjes med at erklære sig uenig $\mathrm{i}$ vurderingen af Sørensens aktualitet og undlader at argumentere mod analysen af Formynderfortallinger (bl.a.), der er præmissen for min vurdering.

Når Søren Schou mener 'at Sørensen i sin diagnose af frihedsproblemet i 60ernes velfærdssamfund faktisk i høj grad kom til at skille den ydre og den indre frihed ad,' så godtgør han det med et citat fra indledningen til Marx' ungdomsskrifter, der for mig at se blot gør opmærksom på at den menneskelige frigørelse ikke er identisk med men aktualiseres af de friheder og den fritid vi har fået flere og mere af. Det er ikke at skille den ydre og indre frihed ad, men nok at påstå (konstatere?) at der ikke betår et simpelt afledningsforhold mellem dem. Der må øves en selvstændig indsats begge steder. Det er også hvad der ligger i det andet citat, fra Hverken-eller: at 'en psykologisk frigørelse må slutte sig til den økonomiske.'

Jeg har ikke sagt at disse citater viser at Sørensen, ligesom Brecht, mener at den materielle behovstilfredsstillelse går forud for moralen, men at de ikke strider mod Brechts anskuelse. Nuanceringen er vigtig, for den peger på accentforskydningen hos Sørensen. Han insisterer på at den relativt omfattende materielle behovstilfredsstillelse $i$ velstandssamfundet sætter den indre personlige frigørelse på dagsordenen, uanset at dette samfund stadig frembringer en række selvstændige fysiske og psykiske sygdomme. Eller netop fordi det gør. Disse sygdomme peger jo på at mennesket har andre behov end at spise og at sove, - der må tilfredsstilles for at vi overhovedet kan fordøje og sove ordentligt. Er det ikke Søren Schou der kommer til at isolere sig selv fra det indre ved på god gammeldags materialistisk vis at underordne det så totalt det ydre at det forsvinder $\mathrm{i}$ det, - f.eks. når han siger at velstandssamfundets fremkomst med dets produktionsomlagninger '- $i$ sig selv var årsag til en række nye (fysiske) og psykiske 
sygdomme ...' Det var vel ikke velstanden i sig selv der var årsagen, men mangler ved den. Og disse mangler var næppe heller blot en følge af produktionsomlægninger. Trods velstanden og flere friheder og større fritid var (er) folk ikke tilfredse, men plaget af angst og ubestemte bekymringer. Sørensen konstaterer at mennesket har behov for ikke bare at leve livet men for at se en mening med at gøre det. Det kræver ændrede samfundsforhold (herunder produktionsomlægninger) men også ændrede samfundsforandrere, der har mod til at udvide deres forestillinger om hvad det er der plager folk. Værdighed er et spørgsmål om ikke at blive trådt på, om at få udviklet et maximum af sine evner, om ikke bare at producere men producere sig selv og opleve sin egen brugsværdi for samfundet. Hvis ikke socialismen i teori og praksis kan tilgodese de enkeltes krav om at gælde noget i sig selv, vil det nye samfund blive en parodi på det gamle. Det er ikke mindst det snakken om det indre og ydre handler om. Den handler om at give plads for det skjulte (fortrængte, uglesete), der afviger fra de objektive, officielle sandheder, bl.a. på venstrefløjen. Den handler f.eks. i praksis om at man som litteratursociolog vender om på den gamle autoritære maxime, der siger at den der ikke er med mig (ofte helt ud i formuleringen, altså jargonen), er imod mig. Som Villy Sørensen siger er det mere liberalt (befriende) at gå udfra at den der ikke er imod mig er med mig. Krisen for det kapitalistiske samfund blev en krise også for venstrefløjen fordi tilslutning i det ydre (til partiet f.eks.) stadig er højere værdsat end tilslutning i det indre (til det venstrefløjen står for).

Jeg synes Sørens Schou fordrejer Sørensens meninger når han fremstiller det som om han stiller sig tilf reds med den ydre frigørelse i velstandssamfundet. Det gør han ikke. Han fastholder at den ikke i sig selv er tilfredsstillende. Har eftertiden i øvrigt ikke givet ham ret? I at samfundsudviklingen, herunder den økonomiske, implicerede 'indre' frigørelsesforsøg. Hvad ville 68 have være uden? Den nye sensibilitet, den religiøse søgen, den overskridende sexualtitet, oprøret i musikken, moden og sproget pegede på lige så mange mangler ved den økonomiske velstand og måden vi var kommet til den på. At beskæftige sig med Sørensen er sådan set ikke at gå bag om 68 men at arbejde videre på indfrielsen af løfter, der blev fornyet i 68 , og afgivet før.

Sørensen har ikke gennem de sidste 10 år været mere interesseret $i$ instinktpsykologi end i socialisationsteori. Hans kritiske interesse for f.eks. Skinners adfærdspsykologi (i Uden mål-og med) viser det. 
Ligesom han ikke kun taler om et behov for ledelse (som han også og måske bedre kalder for samvirke) men tillige om et behov for selvstændighed. I samme åndedrag. Sådan skiller han ikke tingene ad. Det må man gøre for at få ham derhen hvor Søren Schou tilsyneladende stadig vil have ham.

Jorgen Bonde Jensen 